\title{
AKTIVITAS INHIBISI $\alpha$ - AMILASE EKSTRAK MIKROALGA Chlorella vulgaris SEBAGAI KANDIDAT ANTIDIABETES
}

\author{
INHIBITION ACTIVITIES $\alpha$ - AMILASE OF MICROALGAE EXTRACT OF \\ Chlorella vulgaris as CANDIDATE OF ANTIDIABETES
}

\author{
Liska Ramdanawati ${ }^{1}$, Dewi Kurnia ${ }^{1 *}$, Asep Roni ${ }^{1}$, Qonita Alya Kalimatillah ${ }^{1}$, Zeily \\ Nurachman ${ }^{2}$ \\ 1) Fakultas Farmasi, Universitas Bhakti Kencana Bandung, Indonesia-40161 \\ 2) KK Biokimia, Departemen Kimia FMIPA Institut Teknologi Bandung, Indonesia 40132
}

*)E-mail: dewi.kurnia@bku.ac.id

Diterima: 09/12/2019

Direvisi: $10 / 02 / 2020$

Disetujui: 26/04/2020

\begin{abstract}
Abstrak
Terapi dengan obat-obat sintetis yang dilakukan pada penyakit Diabetes Melitus (DM) sering menemui kegagalan, antara lain disebabkan efek samping dan biaya yang tinggi akibat pengobatan jangka panjang. Salah satu sumber daya bahari yang berpotensi besar sebagai bahan baku obat adalah mikroalga seperti Chlorella vulgaris. Pada penelitian ini dilakukan uji aktivitas ekstrak mikroalga $C$.vulgaris dalam menginhibisi $\alpha$-amilase untuk mengetahui potensinya sebagai kandidat obat antidiabetes. Ekstraksi dilakukan terhadap biomassa kering dengan metode maserasi bertingkat menggunakan n-heksana, kloroform dan etanol $96 \%$. Hasil pemantauan ekstrak menggunakan KLT menunjukan bahwa pada ekstrak C.vulgari terdapat senyawa golongan flavonoid, fenol, alkaloid, dan saponin steroid. Penentuan aktivitas inhibisi $\alpha$-amilase dilakukas secara in vitro menggunakan saliva yang bersumber dari manusia, diukur menggunakan spektrofotometer sinar tampak dengan metode Fuwa. Dari ketiga ekstrak yang diujikan, hanya ekstrak n-heksana dan etanol saja yang memberikan aktivitas inhibisi secara berturut-turut yaitu $24,59 \pm 2,83 \%$ dan $47,06 \pm 8,31 \%$. Hasil penelitian menunjukan ekstrak etanol mikroalga C.vulgaris berpotensi untuk dikembangkan sebagai obat antidiabetes alternative dari bahan alam bahari.
\end{abstract}

Kata kunci: Chlorella vulgaris, antidiabetes, inhibisi $\alpha$-amilase

\begin{abstract}
Therapy with synthetic drugs carried out in Diabetes Mellitus (DM) often fails, among others due to side effects and high costs due to long-term treatment. One of the marine resources that has great potential as a raw material for medicines is microalgae such as Chlorella vulgaris. In this study, the activity of C.vulgaris microalgae extract was tested in inhibiting $\alpha$-amylase to determine its potential as a candidate for antidiabetic drugs. Extraction was carried out on dry biomass by multilevel maceration method using n-hexane, chloroform and ethanol 96\%. The monitoring results of extracts using TLC showed that C.vulgaris extract contained flavonoid, phenol, alkaloid, and steroid saponin compounds. Determination of $\alpha$-amylase inhibitory activity was carried out in vitro using saliva sourced from humans, measured using a visible light spectrophotometer by the Fuwa method. Determination of $\alpha$-amylase inhibitory activity was carried out in vitro using human saliva, measured using a visible spectrophotometer by the Fuwa method. Of the three microalgae extracts tested, only n-hexane and ethanol extracts provided inhibitory activity of $24.59 \pm 2.83 \%$ and $47.06 \pm 8.31 \%$, respectively. The results showed ethanol extract of C.vulgaris microalgae has the potential to be developed as an alternative antidiabetic drug from natural marine materials.
\end{abstract}

Keywords: Chlorella vulgaris, antidiabetic, $\alpha$-amylase inhibition 


\section{PENDAHULUAN}

Hiperglikemia adalah penyakit degeneratif yang angka kejadiannya cukup tinggi di berbagai negara dan merupakan salah satu penyakit yang menjadi masalah kesehatan masyarakat [1]. Kebanyakan dari kasus hiperglikemia biasanya akan berlanjut menjadi penyakit diabetes mellitus (DM) dengan ditunjang pemeriksaan klinis, seperti kadar gula darah puasa di atas $126 \mathrm{mg} / \mathrm{dL}$ dan kadar gula darah 2 jam setelah makan di atas $200 \mathrm{mg} / \mathrm{dL}$ [2]. Menurut World Health Organization (WHO), penderita diabetes mellitus di Indonesia menempati urutan ke empat terbanyak di dunia setelah Amerika Serikat, Cina, dan India. Lebih dari 346 juta penduduk dunia mengidap diabetes pada tahun 2010, 422 juta mengidap DM pada tahun 2014, dan 1,5 juta penderita DM meninggal dunia pada tahun 2012. Penderita diabetes di Indonesia hampir $60 \%$ penderitanya tidak menyadari bahwa dirinya telah terkena penyakit tersebut. 21,3 juta orang di antaranya merupakan penderita diabetes di Indonesia pada tahun 2010. Jumlah ini meningkat dari tahun 2000 yang berjumlah 8,4 juta penderita [3].

Kemunculan penyakit diabetes dipengaruhi oleh beberapa faktor, seperti faktor keturunan, pola hidup yang buruk ataupun dalam kondisi tertentu. Faktor pola hidup yang buruk, banyak menimbulkan munculnya kejadian penyakit diabetes sehingga penderita yang tadinya tidak memiliki resiko terkena penyakit diabetes menjadi terkena penyakit tersebut. DM dibagi menjadi dua tipe, yaitu tipe I dan tipe II. Diabetes tipe I merupakan diabetes yang disebabkan ketidakmampuan tubuh dalam memproduksi insulin. Produksi insulin terhambat karena rusaknya sel beta pada pankreas sehingga mutlak diperlukan insulin dari luar. Adapun DM tipe II disebabkan berkurangnya sensitivitas sel targetnya terhadap insulin [4].

Insulin adalah suatu hormon yang dihasilkan oleh sel beta yang terdapat pada organ pankreas yang terdapat dalam tubuh yang dapat merangsang penyerapan glukosa, sintesis lipid [5], dan insulin dapat menghambat pemecahan lemak, protein, glikogen dan menghambat jalur glukoneogenesis. Banyak penderita penyakit diabetes akan terkena serangkaian komplikasi yang menyerang pada penderita seperti nefropati, neuropati, retinopati, kaki diabetes (berbagai macam komplikasi yang menyerang kaki pada penderita diabetes), ketoasidosis , dan peningkatan resiko penyakit kardiovaskular dan hipertensi [6].

Terapi dengan obat-obat sintetis sering menemui kegagalan, antara lain disebabkan efek samping dan biaya yang tinggi akibat pengobatan jangka panjang. Terapi DM yang memakan waktu lama memungkinkan terjadinya pemakaian berasama obat herbal dan antidiabetika oral, selain kurangnya efek samping juga dapat meningkatkan peluang untuk sembuh, minimal dengan kadar glukosa darah yang terkontrol [7]

Salah satu obat antidiabetes herbal adalah daun salam. Pada penelitian sebelumnya, telah terbukti bahwa ekstrak etanol daun salam pada dosis $249.6 \mathrm{mg} / \mathrm{kg}$ BB dapat menurunkan kadar glukosa darah mencit yang diinduksi alokasan [8] Beberapa contoh lain obat herbal antidiabetes adalah Echinacea, gingko biloba, bawang putih , ginseng [9]. Banyaknya sumber bahan alam yang digunakan untuk penggunaan obat DM dikhawatirkan dapat menurunkan populasi spesies tanaman tersebut, sehingga bahan bahari yang menjadi alternatif sumber obat tersebut.

Salah satu sumber daya bahari yang berpotensi besar sebagai bahan obat salah satunya adalah pada organisme mikroalga. Saat ini, studi mengenai mikroalga menjadi menarik karena kondisi pertumbuhannya yang dapat dikontrol dengan mudah di dalam bioreaktor. Selain itu, mikroalga memiliki berbagai senyawa bioaktif yang memiliki peran penting untuk kesehatan dan nutrisi manusia dan telah digunakan secara luas sebagai pangan fungsional, nutraseutikal, dan sediaan farmasi [10]. 
Salah satu diantaranya yang menarik untuk dikembangkan adalah ekstrak yang dihasilkan oleh mikroalga hijau Chlorella vulgaris. Penelitian menunjukkan bahwa ekstrak dari Chlorella sp. memiliki aktivitas anti inflamasi [11], immunomodulator, bahkan polisakarida (ß-(1,3)-glukan dari Chlorella vulgaris sudah dibuktikan memiliki aktivitas biologis dalam pencegahan infeksi dan sebagai antitumor. Pemberian Chlorella sp. secara akut menghasilkan efek hipoglikemik yang signifikan dengan induksi aloksan pada tikus atau streptozotosin pada mencit, namun informasi mengenai aktivitas inhibisi a-amilase secara in vitro dari ekstrak Chlorella vulgaris belum cukup jelas dan perlu untuk dilakukan. Berdasarkan hal tersebut, pada penelitian ini dilakukan uji aktivitas penghambatan enzim $\alpha-$ amilase yang diambil dari saliva manusia oleh beberapa ekstrak mikroalga Chlorella vulgaris.

\section{METODE}

\section{Sampel (Bahan) Penelitian}

Mikroalga yang digunakan dalam penelitian ini adalah kultur murni Chlorella vulgaris yang diperoleh dari Laboratorium Biokimia, Program Studi Kimia, Fakultas Matematika dan Ilmu Pengetahuan Alam, Institut Teknologi Bandung. Bahan-bahan lain yang digunakan dalam penelitian ini antara lain, aquades, alkohol 70\%, garam, kertas saring, kapas lemak, kasa, alumunium foil, media Walne, n-Heksana p.a (Merck), kloroform p.a (Merck), etanol (Merck, 96\%), $\mathrm{AlCl} 3$, sitroborat, FeCle3, pereaksi Liebermann Burchard, pereaksi Dragendorf, $\mathrm{HCl}$ p.a (Merck), $\mathrm{I}_{2}$, KI dan amilum.

\section{Prosedur Kerja}

Penelitian ini dilakukan dalam beberapa tahapan. Tahap pertama yaitu aktivasi dan kultivasi mikroalga Chlorella vulgaris. dalam medium Walne. Tahap kedua, pemanenan mikroalga menggunakan alat sentrifuga Beckmann J2-HS dengan rotor besar (JA 10) pada kecepatan 5.000×g selama 20 menit. Supernatan kemudian dipisahkan dan pellet (biomassa basah) dikumpulkan. Tahap ketiga yaitu sampel mikroalga dilakukan pengeringan dengan metode Freeze Dry. Tahap keempat yaitu karakterisasi simplisia meliputi penentuan kadar abu total, kadar abu tidak larut asam, kadar sari larut etanol, kadar sari larut air, dan susut pengeringan. Tahap selanjutnya adalah pemecahan sel dan ekstraksi dengan cara maserasi bertingkat. Sebanyak $10 \mathrm{~g}$ biomassa kering di maserasi dengan penambahan $50 \mathrm{~mL}$-heksan lalu disonikasi selama 10 menit dan diaduk dengan orbital shaker selama 24 jam, kemudian dipisahkan endapan lalu diuapkan dan diambil ekstrak kental, selanjutnya tambahkan kloroform, etanol 96\% kemudian diuapkan dan diambil ekstrak kental. Tahap kelima yaitu pemantauan ekstrak dengan menggunakan metode kromatografi lapis tipis, dilakukan pemantauan pada ketiga ekstrak setelah itu disemprot dengan penampak bercak $\mathrm{H}_{2} \mathrm{SO}_{4}$, $\mathrm{AlCl}_{3}$, sitroborat, $\mathrm{FeCl}_{3}$, Liebermann Burchard, dan Dragendorf.

Aktivitas penghambatan enzim a-amilase (saliva manusia) oleh pigmen fikosianin ditentukan menggunakan metode FUWA [12] dengan beberapa penyesuaian. Sebanyak $3 \mathrm{~mL}$ larutan saliva ditambahkan $3 \mathrm{~mL}$ larutan fikosianin dan diinkubasi pada suhu $37^{\circ} \mathrm{C}$ selama 15 menit. Campuran ditambah $3 \mathrm{~mL}$ pati $1 \%$ dan diinkubasi kembali pada suhu $37^{\circ} \mathrm{C}$ selama 15 menit. Reaksi dihentikan dengan menambahkan $3 \mathrm{~mL} \mathrm{HCl} 1 \mathrm{~N}$ kemudian ditambahkan $1 \mathrm{~mL}$ larutan iodium. Pati terhidolisis bila menghasilkan larutan kompleks berwarna kuning, dan berwarna biru jika tidak terjadi hisrolisis. 
Larutan diencerkan dengan penambahan aquades kemudian absorbansi diukur dengan menggunakan spektrofotometer UV-Vis pada panjang gelombang $600 \mathrm{~nm}$. Setiap percobaan dilakukan dua kali, dan aktivitas penghambatan a-amilase (\%inhibisi) dihitung dengan menggunakan rumus sebagai berikut:

$$
\text { persen inhibisi }(\%)=\frac{S-B}{S} \times 100
$$

Keterangan : $S=$ Selisih nilai absorbansi sampel dan kontrol sampel

$B=$ Selisih nilai absorbansi blanko dan kontrol blanko

Tabel 1. Prosedur pengerjaan aktivitas inhibisi $\alpha$-amilase

\begin{tabular}{|c|c|c|c|c|}
\hline \multicolumn{5}{|c|}{ PROSEDUR PENGERJAAN } \\
\hline Reagent & Blanko & $\begin{array}{l}\text { Kontrol } \\
\text { Blanko }\end{array}$ & Sampel & $\begin{array}{l}\text { Kontrol } \\
\text { sampel }\end{array}$ \\
\hline $\begin{array}{l}\text { Ekstrak Mikroalgae } \\
(1000 \mathrm{ppm})\end{array}$ & - & - & $1000 \mu \mathrm{L}$ & $1000 \mu \mathrm{L}$ \\
\hline Pelarut Sampel Ekstrak & $1000 \mu \mathrm{L}$ & $1000 \mu \mathrm{L}$ & - & - \\
\hline Pelarut Enzim & - & $1000 \mu \mathrm{L}$ & - & - \\
\hline Enzim & $1000 \mu \mathrm{L}$ & - & $1000 \mu \mathrm{L}$ & - \\
\hline \multicolumn{5}{|c|}{ Vortex 15", Inkubasi 15' } \\
\hline Amilum 1\% & $1000 \mu \mathrm{L}$ & $1000 \mu \mathrm{L}$ & $1000 \mu \mathrm{L}$ & $1000 \mu \mathrm{L}$ \\
\hline \multicolumn{5}{|c|}{ Vortex 15", Inkubasi 15' } \\
\hline $\mathrm{HCl} 1 \mathrm{~N}$ & $1000 \mu \mathrm{L}$ & $1000 \mu \mathrm{L}$ & $1000 \mu \mathrm{L}$ & $1000 \mu \mathrm{L}$ \\
\hline $\mathrm{I}_{2}$ dalam KI $(0,2 \%)$ & $500 \mu \mathrm{L}$ & $500 \mu \mathrm{L}$ & $500 \mu \mathrm{L}$ & $500 \mu \mathrm{L}$ \\
\hline
\end{tabular}

\section{HASIL DAN PEMBAHASAN}

Mikroalga yang digunakan adalah mikroalga laut Chlorella vulgaris yang diperoleh dari Laboratorium Biokimia ITB. Kultur diperoleh dalam keadaan axenic yaitu hanya memiliki satu jenis mikroalga dalam medium cair, tidat terdapat kontaminan mikroorganisme lainnya. Bentuk sel dari mikroalga Chlorella vulgaris adalah bulat dan berwarna hijau (Gambar 1).

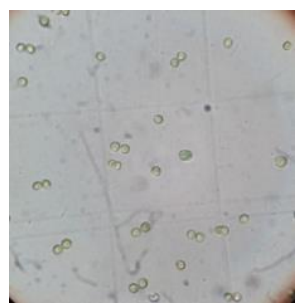

Gambar 1. Mikroalga Chlorella vulgaris di bawah mikroskop dengan perbesaran 40x 
Pengumpulan biomassa mikroalga dilakukan dengan cara kultivasi menggunakan bioreaktor sederhana. Kondisi lingkungan kultivasi antara lain menggunakan suhu ruang $\left( \pm 25-27^{\circ} \mathrm{C}\right)$, fotoperiode 12:12 (gelap:terang) dengan intensitas cahaya 10,000 lux dan aerasi selama 24 jam. Kultivasi mikroalga dilakukan dengan menggunakan medium Walne dan kepadatan sel dimulai dari $1 \times 10^{6} \mathrm{sel} / \mathrm{mL}$. Pemanenan dilakukan pada hari ke-8, saat pemanenan dilakukan perhitungan sel rata-rata. Untuk mengetahui kepadatan biomassa yang diperoleh, kemudian pemanenan mikroalga Chlorella vulgaris dilakukan dengan menggunakan alat sentrifuga Beckmann J2-HS dengan rotor besar (JA 10) pada kecepatan 8.000×g selama 20 menit sehingga diperoleh biomassa basah (gambar 2). Selanjutnya biomassa basah dikeringkan cara beku-kering agar kandungan air pada biomassa tidak mengganggu proses ekstraksi serta sampel biomassa mikroalga bertahan lama dan tidak ditumbuhi oleh jamur.

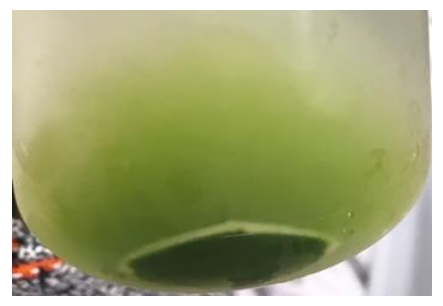

Gambar 2. Biomassa Basah Hasil Sentrifuga Mikroalga Chlorella vulgaris

Ekstraksi menggunakan metode maserasi bertingkat dengan menggunakan pelarut n-heksana, kloroform, dan etanol. biomassa kering yang digunakan 10 gram dengan masing-masing pelarut $50 \mathrm{~mL}$, dilakukan tiga kali pengulangan, dilakukan selama 24 jam. Hasil rendemen ekstrak dapat dilihat pada tabel 2.

Tabel 2. Hasil Rendemen Ekstrak Mikroalga Chlorella vulgaris

\begin{tabular}{|c|c|c|}
\hline No. & Pelarut & Rendemen (\%) \\
\hline 1. & N-heksana & 10,8 \\
\hline 2. & Kloroform & 42,2 \\
\hline 3. & Etanol & 22,2 \\
\hline
\end{tabular}

Pemantauan ekstrak n-heksana, kloroform, dan etanol dilakukan dengan menggunakan fase diam KLT Silika Gel $\mathrm{F}_{254}$ dengan menggunakan pengembang n-heksana - etil asetat $(7: 3)$, n-heksana - kloroform - etanol ( $5: 4: 1$ ), etil asetat - etanol - aquadest ( $9: 0,5: 0,5$ ). Penampak bercak yang digunakan $\mathrm{H}_{2} \mathrm{SO}_{4} 10 \%, \mathrm{FeCl}_{3} 10 \%, \mathrm{AlCl}_{3}$, sitroborat, Dragendorf, dan Liebermann Burchard. Hasil dari pemantauan ekstrak dapat dilihat pada Gambar 3. 


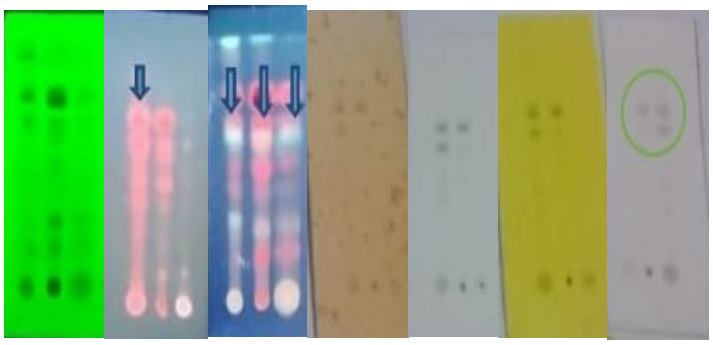
(a)
(c) (d)
(e)
(f)
(g)
(h)

A

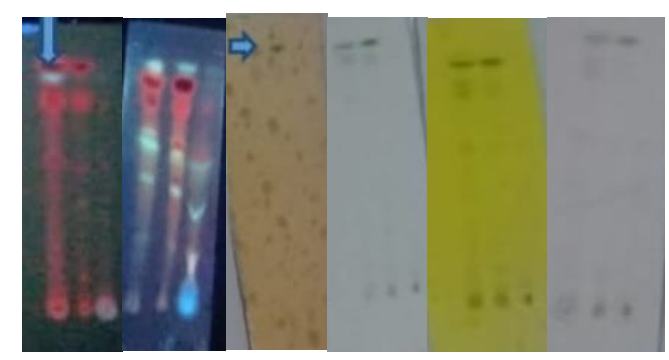

(b) (d) (e) (f) (g) (h)

B

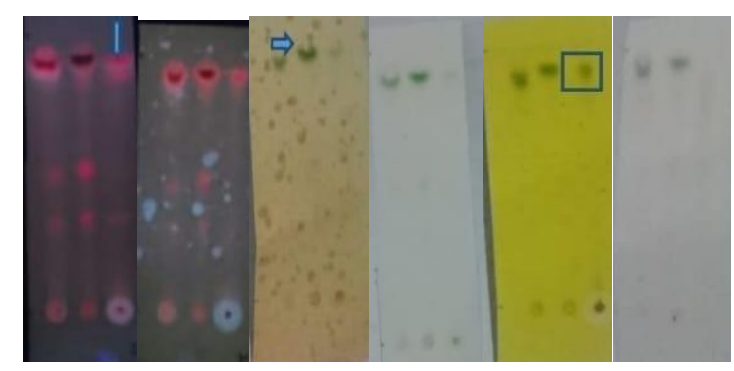
(c) (d) (e)
(f )
(g)
(h)

C

Gambar 3. Hasil pemantauan ekstrak mikroalga Chlorella vulgaris dengan KLT kromatogram lapis tipis ekstrak n-heksana, kloroform dan etanol dari mikroalga Chlorella vulgaris, fase diam silica gel F254 dan pengembang (A) n-heksana - etil asetat (7:3), (B) n-heksana kloroform - etanol ( $5: 4: 1$ ), (C) etil asetat - etanol - aquadest ( $9: 0,5: 0,5$ ). (1) ekstrak nheksana, (2) ekstrak kloroform, (3) ekstrak etanol, (a) Sinar UV $\lambda 254 \mathrm{~nm}$, (b) Sinar UV $\lambda$ $366 \mathrm{~nm}$, (c) penampak bercak sitroborat dibawah sinar UV $366 \mathrm{~nm}$, (d) penampak bercak $\mathrm{H} 2 \mathrm{SO} 4$ 10\%, (e) penampak bercak $\mathrm{FeCl}$, (f) penampak bercak $\mathrm{AlCl} 3$, (g) penampak bercak Dragendorf, (h) penampak bercak Liebermann burchard.

Keterangan: $\mathbb{l}$ : positif bercak flavonoid

$\rightarrow$ : positif fenol

: positif saponin steroid 


\section{: positif alkaloid}

Penampak bercak yang dipakai diantaranya $\mathrm{H}_{2} \mathrm{SO}_{4} 10 \%$ sebagai penampak bercak universal dimana bisa melihat seluruh komponen senyawa dalam ekstrak. Lalu digunakan penampak bercak $\mathrm{FeCl}_{3}$ 10\% untuk melihat adanya golongan senyawa fenol ditunjukkan dengan hasil positif yaitu bercak berwarna biru kehitaman dengan latar kuning. Kemudian digunakan penampak bercak $\mathrm{AlCl}_{3}$ untuk mendeteksi flavonoid dengan hasil positif yaitu bercak warna biru. Selanjutnya digunakan penampak bercak sitroborat untuk melihat adanya golongan senyawa flavonoid ditunjukkan dengan hasil positif yaitu adanya bercak berwarna kuning kehijauan saat dilihat dibawah sinar lampu UV $365 \mathrm{~nm}$. Penampak bercak Liebermann Burchard digunakan untuk menunjukkan adanya saponin steroid yang ditunjukkan dengan bercak berfluorosensi hijau dan biru dan saponin triterpenoid yang ditujukkan dengan bercak berwarna orange kemerahan. Penampak bercak Dragendorf digunakan untuk mendeteksi adanya senyawa alkaloid ditandai dengan bercak berwarna coklat kehitaman.

Dari hasil ketiga pengujian dengan fase gerak non polar, semi polar dan polar yang disemprot dengan beberapa macam penampak bercak dapat disimpulkan bahwa pada ekstrak non polar diperkirakan terdapat senyawa flavonoid, fenol dan saponin steroid, pada ekstrak semi polar diperkirakan terdapat senyawa flavonoid dan ekstrak polar terdapat senyawa flavonoid, fenol dan alkaloid. Ringkasan hasil karakterisasi ekstrak dapat dilihat pada tabel 3.

Tabel 3. Karakterisasi ekstrak

\begin{tabular}{|c|l|c|c|c|}
\hline \multirow{2}{*}{ No. } & \multicolumn{1}{|c|}{ Golongan } & \multicolumn{3}{|c|}{ Ekstrak } \\
\cline { 3 - 5 } & senyawa & n-heksana & Kloroform & EtOH \\
\hline 1. & Flavonoid & + & + & + \\
2. & Fenolat & - & + & - \\
3. & Steroid & - & + & + \\
4. & Alkaloid & - & - & + \\
5. & Terpenoid & - & - & - \\
\hline
\end{tabular}

Aktivitas antidiabetes ditentukan dengan metode inhibisi $\alpha$-amilase yang bersumber dari saliva manusia (salivary enzyme). Saliva mempunyai pH optimum 5,75 - 7,05 dan suhu optimum yaitu $37^{\circ} \mathrm{C}$ [13]. Saliva yang digunakan diperoleh dari sukarelawan sehat, tidak terkena diabetes mellitus, tidak sedang mengkonsumsi obat-obatan apapu dengan usia sekitar 22-25 tahun. Pemilihan sumber saliva didasarkan pada tujuan pengaplikasian ekstrak mikoalga $C$. vulgaris sebagai agen antidiabetes dengan cara menghambat kerja enzim aamilase, dimana a-amilase dalam tubuh terdapat pada saliva dan pankreas. Saliva manusia memiliki kesamaan fisiologis dengan keadaan yang sebenarnya dalam proses metabolisme karbohidrat dalam tubuh manusia dibandingkan a-amilase dari sumber lain.

Pengujian inhibisi enzim $\alpha$-amilase adalah uji untuk mengetahui penurunan aktivitas enzim a-amilase dalam memecah pati sehingga hasilnya adalah penurunan daya cerna pati. Semakin rendah daya cernasuatu pati berarti semakin sedikit pati yang dapat dihidrolisis dalam waktu tertentu. Pati dapat berekasi dengan pereaksi iodium sehingga kadar pati sisa dapat diukur secara spektrofotometri pada panjang gelombang $600 \mathrm{~nm}$. 
Semakin besar nilai absorbansi maka semakin besar persen inhibisi sampel, begitu juga sebaliknya. Aktivitas inhibisi dapat diamati melalui warna larutan yang terbentuk. Warna larutan uji ditunjukan pada Gambar 4.

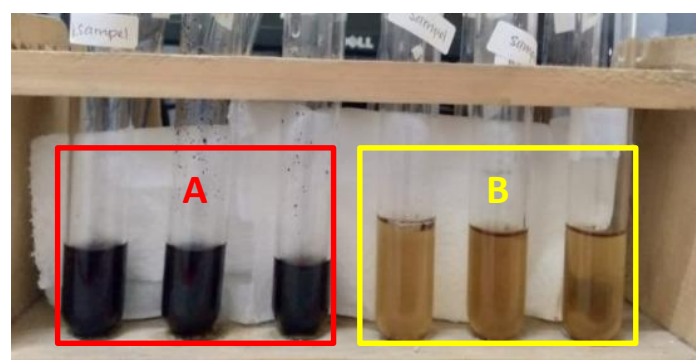

Gambar 4. Pengujian inhibisi $\alpha$-amilase terhadap pati oleh ekstrak mikroalga C.vulgaris; A) Kontrol sampel ekstrak etanol; B) aktivitas inhibisi ekstrak etanol

Pengujian aktivitas inhibisi $\alpha$-amilase menggunakan ekstrak mikroalga pada pelarut $\mathrm{n}$ heksan, kloroform dan etanol dengan konsentrasi 1000 ppm. Tabel 4 menunjukan nilai \% inhibisi $\alpha$-amilase dari saliva manusia oleh ekstrak mikroalga.

Tabel 4. Aktivitas inhibisi ekstrak C. vulgaris terhadap enzim saliva manusia

\begin{tabular}{|c|c|c|}
\hline No. & Pelarut ekstrak & $\%$ inhibisi \\
\hline 1. & n-heksana & $24,59 \pm 2,83$ \\
2. & kloroform & - \\
3. & etanol & $47,06 \pm 8,3$ \\
\hline
\end{tabular}

Berdasarkan data diatas, diketahui dari ketiga ekstrak yang diuji, hanya ekstrak mikroalgan dengan pelarut $n$-heksan dan etanol saja yang memberikan aktivitas inhibisi enzim $\alpha$-amilase sedangkan ekstrak kloroform tidak menunjukan adanya aktivitas penghambatan. Ekstrak etanol mikroalga C.vulgaris menunjukan aktivitas inhibisi yang cukup tinggi, sehingga pada ekstrak tersebut dapat dilakukan pengujian lebih lanjut untuk mengetahui potensi mikroalga C.vulgaris sebagai kandidat obat antidiabetes. Beberapa penelitian menyatakan bahwa terdapat metabolit sekunder pada mikroalga yang berfungsi untuk mengontrol kadar glukosa darah melalui inhibisi enzim pemecahan karbohidrat dan enzim protein tirosin fosfatase 1B, kepekaan terhadap insulin, efek penyerapan glukosa dan efek perlindungan lainnya terhadap komplikasi diabetes. Oleh karena itu, studi mengenai isolasi, karakterisasi, dan studi farmakologis terhadap mikroalga perlu dieksplorasi lebih dalam untuk dapat menemukan senyawa antidiabetes baru dengan nilai biomedis yang tinggi [14].

\section{KESIMPULAN}

Ekstrak n-heksan dan etanol dari mikroalga C.vulgaris diketahui memiliki aktivitas inhibisi $\alpha$-amilase. Nilai \% inhibisi ekstrak n-heksan dan etanol secara berturut-turut adalah $24.59 \pm$ $2.83 \%$ and $47.06 \pm 8.31 \%$. Hasil penelitian menunjukan ekstrak etanol mikroalga C.vulgaris berpotensi untuk dikembangkan sebagai obat antidiabetes alternatif dari bahan alam bahari. 


\section{UCAPAN TERIMA KASIH}

Ucapan terimakasih penulis ucapkan kepada Kementerian Riset, Teknologi dan Pendidikan

Tinggi Republik Indonesia (Kemenristekdikti) atas pendanaan penelitian ini melalui Hibah Penelitian Dosen Pemula tahun pendanaan 2019.

\section{DAFTAR RUJUKAN}

1. Departemen Kesehatan, R. I. (2005). Pharmaceutical care untuk penyakit Diabetes Mellitus. Direktorat Bina Farmasi Komunitas Dan Klinik, Direktorat Jenderal Bina Kefarmasian Dan Alat Kesehatan.

2. Sukandar,E.Y., 2009, ISO Farmakoterapi, PTISFI. Jakarta.

3. World Health Organization, 2014, Definition, diagnosis andclasification of diabetes melitus and itscomplications, Geneva, WHO Publishing.

4. Dalimartha,S. 2000. Atlas Tumbuhan Obat Indonesia. Trubus Agrowidya. Bogor.

5. Barde, S.R., Sakhare, R.S., Kanthale, S.B., Chandak, P.G., Jamkhande, P.G. Marine bioactive agents: A short review on new marine antidiabetic compounds. Asian Pac. J. Trop. Dis. 2015, 5, S209-S213.

6. Liu, Y., Gao, Z., Guo, Q., Wang, T., Lu, C., Chen, Y., Sheng, Q., Chen, J., Nie, Z., Zhang,Y., et al. Anti-Diabetic Effects of CTB-APSL Fusion Protein in Type 2 Diabetic Mice.Mar. Drugs 2014, 12, 1512-1529.

7. Marianne, Yuandani, Rosnani, 2011, Antidiabetic Act ivit y from etanol ekstrak of kluwih's leaf ( Artocarpus camansi ), jurnal natural vol.11 (2).

8. Carolina, R. (0310149). 2007. Pengaruh ekstrak Daun Salam (Polyanthi Folium) terhadap Kadar Glukosa darah mencit jantan galur Balb/C yang diinduksi Aloksan. Other thesis, Universitas Kristen Maranatha.

9. Graham, R. E., Gandhi, T.K., Borus J., Seger, A.C., Burdick, E., Bates, D.W., Phillips, R.S.,Weingart, S.N., 2008, Risk of Concurrent Use of Prescription Drugs with Herbal and Dietary Supplements in Ambulatory Care, 1, NIH, Boston.

10. Vankatesan, J., Manivasagan, P., dan Kim, S.K. (2015): Marine Microalgae Biotechnology: Present trends and future advances. Handbook of Marine Microalgae, Elsevier Inc, London.

11. Kurnia, D., Prisdayanti, N., Marliani, L., Idar, I., \& Nurochman, Z. (2019). Antiinflammatory Activity from Marine Microalgae Chlorella vulgaris Extract Used Human Red Blood Cells Stability Method (HRBC). Jurnal Kartika Kimia, 2(2), 57-62.

12. Xiao, Z., Storms, R., \& Tsang, A. (2006). A quantitative starch-iodine method for measuring alpha-amylase and glucoamylase activities. Analytical Biochemistry, 351(1), 146-148.

13. Arunsasi, Manthiri Kani S, Jegadeesh G and Ravikumar M.(2010).Submerged Fermentation Of Amylase Enzyme Byaspergillus Flavus Using Cocos Nucifera Meal. Kathmandu University Journal Of Science, Engineering And Technology. Department of plant biology and plant biotechnologyGovt. Arts College for men's, Nandanam, Chennai. 6(2). 75-87 
14. Unnikrishnan, Pulikkaparambil Sasidharan \& Jayasri, Mangalam Achuthananda, "Marine Algae As A Prospective Source For Antidiabetic Compounds - A Brief Review", Current Diabetes Reviews (2018) 14: 237. https://doi.org/10.2174/1573399812666161229151407 